\title{
КЛАСИФІКАЦІЯ ПУБЛІЧНИХ ПОСЛУГ У СФЕРІ СПРАВЛЯННЯ ПОДАТКІВ
}

\author{
ЛАШКУН Анастасія Ігорівна - начальник управління супроводження \\ судових справ Східного міжрегіонального управління ДПС по роботі з великими \\ платниками податків \\ УДК 342.228+342.7 \\ DOI 10.32782/LAW.UA.2021.4.20
}

Метою наукової статті $\varepsilon$ висвітлення класифікаиї публічних послуг у сфері справляння податків. Методами статті склала сукупність сучасних методів і прийомів пізнання об'єктивної дійсності, щзо поєднує як загальнонаукові, так і спеціальні методи пізнання. Підгрунтям дослідження є діалектичний метод пізнання, відповідно до якого проблеми, що розглядаються у дисертаиї, представлені у вигляді єдності їх соціального змісту та юридичної борми.

Результатами є розгляд різних підходів щодо класифікаиї публічних послуг у сфері справляння податків та дається власна класибікаиія надання ицх послуг. За критерієм змісту пропонуємо виділити такі їх публічні послуги у сбері справляння податків: реєстраизйні (наприклад, реєстрація книги обліку доходів та книги обліку доходів і витрат платникам єдиного податку; реєстрачія реєстратора розрахункових операцій; реєстрачіл платника податку на додану вартість тощо); ліщензійні (переобормлення лічензї на право зберігання пального; видача лічензії на право роздрібної торгівлі алкогольними напоями; видача ліцензї на право роздрібної торгівлі тютюновими виробами; видача ліщензї на право оптової торгівлі спиртом етиловим, спиртом етиловим ректибікованим виноградним, спиртом етиловим ректибікованим плодовим тощо); засвідчувальні або довідкові (наприклад, видача довідки про подану декларачію про майновий стан $і$ доходи (податкову деклараціюо); Видача довідки про подану декларащію про майновий стан $i$ доходи (податкову декларацію); видача довідки про сплату податкових зобов'язань платником податку - резидентом, який виїждае за кордон на постійне місие проживання, та про відсутність податкових зобов'язань; інбормащійні (надання витягу 3 реєстру платників єдиного податку; надання витягу з Реєстру неприбуткових установ та організацій; надання витягу з реєстру платників податку на додану вартість тощо).

Ключові слова: послуга, види, публічна послуга, класифікаиія, класифікачія публічних послуг у сбері справляння податків.

Класифікація (від лат. classis - розряд, клас i facio - роблю, розкладаю) - система розподілу предметів, явищ або понять на класи, групи тощо за спільними ознаками, властивостями [21, с. 175]. Наукова класифікація фіксує закономірні зв'язки між класами об'єктів з метою визначення місця об'єкта в системі, яке вказує на його властивості [14, с. 305]. Методологічно правильно проведена класифікація одночасно підсумовує результати попереднього розвитку цієї галузі пізнання і разом з тим свідчить про початок нового етапу в іiі розвитку. Класифікація сприяє руху науки зі ступеня емпіричного накопичення знань на рівень теоретичного синтезу. Класифікація, що базується на наукових основах, не тільки дає в розгорнутому вигляді картину стану науки або їі фрагмента, але і дозволяє робити обгрунтовані прогнози щодо невідомих ще фактів або закономірностей [22, с. 305]. 
У зв'язку з цим необхідно встановити критерії класифікації публічних послуг, що дозволять найбільш повно відобразити їх систему, та визначити подальші перспективи нормативно-правого регулювання діяльності ДФС України щодо надання послуг юридичним та фізичним особам.

Найбільш повну класифікацію публічних послуг здійснила Г. М. Писаренко в дисертаційному дослідженні «Адміністративні послуги в Україні: організаційно-правові аспекти» $[11$, с. 7], яку, на нашу думку, можна використати для встановлення видів публічних послуг, що надаються органами ДФС. Одним із критеріїв класифікації публічних послуг учена називає зміст адміністративної діяльності щодо надання публічних послуг та виділяе такі їх види: видача дозволів, у тому числі акредитація, атестація, сертифікація; реєстрація 3 веденням реєстрів, у тому числі легалізація суб'єктів (наприклад, легалізація об'єднань громадян; легалізація актів (консульська легалізація документів), нострифікація; соціальні послуги - визнання певного статусу, прав особи (наприклад, призначення пенсій, субсидій].

Згадану класифікацію використовують і інші вчені [4, с. 174].

За вказаним класифікаційним критерієм В. В. Петьовка виділяє шість видів публічних послуг: адміністративні послуги у сфері дозвільної діяльності; адміністративні послуги у сфері забезпечення пожежної безпеки; послуги у сфері ліцензування (ліцензійні адміністративні послуги); послуги, пов’язані з державною реєстрацією (реєстраційні адміністративні послуги; легалізаційні адміністративні послуги (легалізація актів, нострифікація, верифікація]; інформаційні адміністративні послуги [10, c. 56].

О.В. Гринцов, аналізуючи систему публічних послуг, які надаються органами ДФС, вказує, що за змістом адміністративної діяльності органів ДФС щодо їх надання доцільно виділяти: видачу довідок; реєстрацію із веденням реєстрів; надання та відкликання дозволів; надання та відкликання спеціальних дозволів (ліцензій][5, c. 112-113].
Наведені класифікаційні критерії і групи повинні сприйматися крізь призму законодавчого регулювання сервісної діяльності органів ДФС, їх завдань та функцій, а також сутності публічних послуг.

Не викликає заперечень виокремлення серед усієї сукупності публічних послуг, що надаються органами ДФС, дозвільних та реєстраційних.

Також ДФС до публічних послуг віднесено [15] такі види адміністративної діяльності: анулювання дозволу, зупинення дії дозволу, видача дубліката ліцензії, видача додатків до ліцензії, які навряд чи можна віднести до дозвільних публічних послуг в авторському розумінні. Проте вони можуть бути віднесені до публічно-сервісної діяльності органів ДФС у частині прийняття заяви та необхідних документів від платника для вчинення вказаних дій та отримання результату таких послуг. Щодо видачі дубліката ліцензії, то така діяльність органів ДФС, хоча і спрямована на оформлення умов реалізації суб'єктом господарювання свого права - провадити діяльність відповідно до ліцензії, однак не має своїм результатом реалізацію владних повноважень органів ДФС.

До реєстраційних публічних послуг, що надаються органами ДФС, також необхідно віднести і реєстрацію платників податків, відомості щодо яких не міститься у СДР, та видачу довідки про зняття з обліку платника податків, відомостей щодо яких не міститься в ЄДР, враховуючи наступне. Закон України «Про внесення змін до деяких законів України щодо взяття на облік юридичних осіб та фізичних осіб - підприємців» від 24.05.2012 № 4839 [13] скасував необхідність отримувати довідки про взяття на облік платника податків юридичним особам та фізичним особам, дані щодо яких містяться в ЄДР, до якого однак не включаються відомості про фізичних осіб, які здійснюють незалежну професійну діяльність (адвокати, нотаріуси), та юридичних осіб (іх відокремлених підрозділів), для яких законом установлено особливості державної реєстрації (військові частини). Аналогічне можна сказати і про довідку про зняття з обліку вказаної категорії платників податків. 


\section{Цивільне, підприємницьке, господарське та трудове право}

Аналіз окремих законодавчих актів вказує на необхідність доповнити Тимчасовий перелік [15] і такою послугою, як реєстрація витратоміра в Єдиному державному реєстрі витратомірів - лічильників обсягу виробленого спирту етилового (далі - Сдиний реєстр витратомірів], що є, відповідно до частини 5статті 2 Закону України від 19 грудня 1995 року № 481/95-ВР «Про державне регулювання виробництва та обігу спирту етилового, коньячного і плодового, алкогольних напоїв та тютюнових виробів», необхідною передумовою реєстрації акцизних складів у Сдиному державному реєстрі місць зберігання [14].

Незважаючи на важливість реєстрації витратомірів для подальшої реалізації прав платників податків у сфері обігу спирту, алкогольних напоїв та тютюнових виробів, процедури здійснення такої діяльності залишають неврегульованими. Так, Порядком ведення Єдиного державного реєстру витратомірів, затвердженим Постановою Кабінету Міністрів України від 9 жовтня 2013 р. № 806 [16] визначено види інформації, що вноситься до відповідного реєстру, а також посадових осіб, уповноважених реєструвати витратоміри, якими є призначені наказом керівника органу ДФС представники органів ДФС на акцизному складі. Внесення відомостей до Єдиного реєстру витратомірів здійснюється за допомогою програмного продукту, що забезпечує доступ до такого реєстру.

Невизначеними залишаються підстави, порядок, строки та спосіб об'єктивації (наприклад, видача довідки, надання витягу 3 реєстру) надання послуги з реєстрації витратоміра у Сдиному державному реєстрі витратомірів. Усунення названого недоліку правового забезпечення вбачається за рахунок визнання такої діяльності адміністративною послугою та формування відповідних інформаційних та технологічних карток.

Системний аналіз нормативних актів, що встановлюють перелік публічних послуг, які уповноважені надавати органи ДФС, дає підстави стверджувати, що окремі адміністративні послуги органів ДФС не можна назвати ні реєстраційними, ні до- звільними, ні послугами з легалізації актів, ні соціальними послугами. Так, засвідчення довідки про проведення декларування валютних цінностей, доходів та майна, що належать резиденту України і знаходяться за її межами, навряд чи є дозволом, чи реєстрацією. Аналогічне потрібно зазначити і про послуги щодо видачі на запит імпортера сертифіката підтвердження доставки, яким засвідчується факт надходження в Україну товарів, визначених у зазначеному сертифікаті; підтвердження статусу податкового резидента України; видачу довідки про сплату податку на доходи фізичних осіб платником податку - резидентом, який виїжджає за кордон на постійне місце проживання, та про відсутність податкових зобов’язань з цього податку; видачу довідки про подану декларацію про майновий стан і доходи (податкову декларацію), видачу довідки про сплачений нерезидентом в Україні податок на прибуток (доходи).

Враховуючи викладене, пропонуємо такий клас публічних послуг називати засвідчувальними адміністративними послугами. Підтвердити таку пропозицію можна за допомогою підходу, відповідно до якого здійснюється розмежування реєстраційних та посвідчувальних проваджень. Під засвідчувальним провадженням мається на увазі врегульована адміністративно-процесуальними нормами діяльність компетентних адміністративних органів із вирішення конкретних справ, пов'язаних із офіційним посвідченням (підтвердженням] від імені держави суб'єктивних прав, правового статусу або відповідності діяльності фізичної або юридичної особи встановленим у законодавстві вимогам, інших юридичних фактів [1, с. 305].

Проте з формального погляду довідки не можуть бути віднесені до публічних послуг, оскільки не відповідають законодавчому визначенню цього інституту. Однак, як зазначають автори Науково-практичного коментарю до Закону України «Про адміністративні послуги», 3 мотивів практичної доцільності можливо зробити виняток для довідок, які мають стандартизовану форму, їх часто замовляють і вони мають самостійну цінність для суб'єктів звернення [9, с. 36].- 
Зазначене також закріплено у частині 3 статті 3 Закону України від 6 вересня 2012 року № 5203-УІ «Про адміністративні послуги», зокрема, що вимоги цього Закону поширюються на надання суб'єктом надання публічних послуг витягів та виписок з реєстрів, свідоцтв, довідок, копій, дублікатів документів та інші передбачені законом дії, у результаті яких суб'єкту звернення, а також об'єкту, що перебуває в його власності, володінні чи користуванні, надається або підтверджується певний юридичний статус та/або факт [12]. У зв'язку з цим пропонуємо до переліків/реєстрів публічних послуг включати видачу довідок у випадку, коли вони мають усталену форму, передбачену законодавством [9, с. 36].

Аналізуючи адміністративну діяльність органів ДФС, необхідно згадати й інформаційні адміністративні послуги органів ДФС. На використанні їх у діяльності органів державної влади наголошує Ж. В. Завальна [6, с. 214], В. В. Петьовка [10, с. 56], а Ю. М. Ільницька [7, с. 115] доводить їх застосування у діяльності органів місцевого самоврядування. Н. В. Путило та С. Мігіна також пропонують у своїх розробках виділити інформаційні адміністративні послуги, що надаються органами ДФС. Так, на думку Н. В. Путіло, лише незначна частина проявів функцій держави може бути зведена до послуг.

Насамперед це надання інформації (правової та особливо правозастосовної), а також різні форми консультативної та іншої підтримки. Усе інше - це обов'язки держави, обумовлені ії природою та призначенням [20, с. 6]. С. Мігін вважає, що потрібно розрізняти функції та послуги. Якщо громадянин вимушений звертатися до держави для вирішення певного питання і у нього немає альтернативи (тобто він не може вирішити це питання у приватному порядку), то маємо справу з функцією держави (наприклад, ліцензування). Якщо вирішення певного питання є добровільним і у цій сфері існує (або потенційно може існувати) конкурентний ринок, то це - послуга (наприклад, державна експертиза) [8]. Так само і С. Г. Бабелюк переконаний, що одним з найбільш важливих інди- каторів, що відрізняють діяльність 3 надання державних послуг, є добровільна участь громадянина або юридичної особи у правовідносинах. Тому ні реєстраційна діяльність, ні ліцензування чи видача паспорта не $є$ наданням державних послуг [3, с. 16]. Проте, виходячи із законодавчої концепції адміністративної послуги, і реєстрація, і ліцензування, і дозвільна діяльність 6 адміністративними послугами, однак вказане вище актуалізує дослідження інформаційних публічних послуг.

\section{Висновки}

Таким чином, за критерієм змісту пропонуємо виділити такі їх публічні послуги у сфері справляння податків:

- реєстраційні (наприклад, реєстрація книги обліку доходів та книги обліку доходів і витрат платникам єдиного податку; реєстрація реєстратора розрахункових операцій; реєстрація платника податку на додану вартість тощо);

- ліцензійні (переоформлення ліцензії на право зберігання пального; видача ліцензії на право роздрібної торгівлі алкогольними напоями; видача ліцензії на право роздрібної торгівлі тютюновими виробами; видача ліцензії на право оптової торгівлі спиртом етиловим, спиртом етиловим ректифікованим виноградним, спиртом етиловим ректифікованим плодовим тощо);

- засвідчувальні або довідкові (наприклад, видача довідки про подану декларацію про майновий стан і доходи (податкову декларацію); Видача довідки про подану декларацію про майновий стан і доходи (податкову декларацію); видача довідки про сплату податкових зобов'язань платником податку - резидентом, який виїжджає за кордон на постійне місце проживання, та про відсутність податкових зобов'язань;

- інформаційні (надання витягу 3 реєстру платників єдиного податку; надання витягу 3 Реєстру неприбуткових установ та організацій; надання витягу з реєстру платників податку на додану вартість тощо). 


\section{Цивільне, підприсмницьке, господарське та трудове право}

\section{入ітература}

1. Административное право России. Общая часть [Текст] : [учеб. для выс. учеб. завед.] / под ред. П. И. Кононова. - М. : Факт, 2006. - 416 с.

2. Адміністративні послуги : Офіційний сайт Державної фіскальної служби України [Електронний ресурс]. - Режим доступу : http://zakon2.rada.gov.uahttp:// sta-sumy.gov.ua/diyalnist-/ administrativniposlugi/.

3. Бабелюк Е. Г. Основные условия государственных услуг / Е. Г. Бабелюк // Государство и право. - 2006. - № 8. - С. 15-16.

4. Виконавча влада і адміністративне право / за заг. ред. В. Б. Авер'янова. - К.: Ін-Юре, 2002. - 668 c.

5. Гринцов О. В. Система публічних послуг, які надаються органами Державної фіскальної служби України / О. В. Гринцов // Науковий вісник Ужгородського національного університету. - 2014. - № 28. T. 2 - C. 111-114.

6. Завальна Ж. В. Щодо питання про інформаційні адміністративні послуги органів державної влади / Ж. В. Завальна // Вісник Харківського національного університету імені В. Н. Каразіна. Серія «ПРАBО».- 2012. - № 12. - С. 211-214. - (Серія «РАВО»).

7. Ільницька Ю. М. Поняття та ознаки інформаційних публічних послуг органів місцевого самоврядування / Ю. М. Ільницька // Право і безпека. - 2011. - № 3. - С. 114 118.

8. Мигин С. Властные полномочия и государственные услуги [Электронный ресурс] / С. Мигин. - Режим доступа: http:// www.smb.ru/ experts.html? mode $=$ opinions\&i $\mathrm{d}=$ migin\&op $=1227521705$.

9. Науково-практичний коментар до Закону України «Про адміністративні послуги» / за заг. ред. В. П. Тимощука. - К. : ФОП Москаленко О.М., 2013. - 392 с.

10. Петьовка В. В. Надання публічних послуг в Україні: теорія і практика: монографія / В. В. Петьовка; ред.: А. О. Селіванов. - К.: Аогос, 2014. -213 с.

11. Писаренко Г. М. Адміністративні послуги в Україні: організаційно-правові аспекти : автореф. дис. на здобуття науко- вого ступеня кандидата юридичних наук : спец. 12.00.07 - адміністративне право і процес; фінансове право; інформаційне право / Ганна Миколаївна Писаренко. Одеса, 2006. - 20 с.

12. Про адміністративні послуги : Закон України: від 6 вересня 2012 року № 5203VI [Електронний ресурс] - Режим доступу : http://zakon4.rada.gov.ua/laws/show/5203-17.

13. Про внесення змін до деяких законів України щодо взяття на облік юридичних осіб та фізичних осіб - підприємців : Закон України: від 24.05.2012 р. № 4839-VI // Відомості Верховної Ради (ВВР). - 2013. № 15 . - ст. 115 .

14. Про державне регулювання виробництва і обігу спирту етилового, коньячного і плодового, алкогольних напоїв та тютюнових виробів : Закон України : від 19 грудня 1995 року № 481/95-ВР // Відомості Верховної Ради України (ВВР). - 1995. № 46. - ст. 345 .

15. Про затвердження інформаційних карток адміністративних послуг: наказ ДФС України: від 13.01.2015 № 7 [Електронний ресурс]. - Режим доступу : http://sfs. gov.ua/.

16. Про затвердження Порядку ведення Єдиного реєстру товарно-транспортних накладних на переміщення спирту етилового та алкогольних напоїв і Порядку ведення Єдиного державного реєстру витратомірів - лічильників обсягу виробленого спирту етилового : Постанова Кабінету Міністрів України: від 9 жовтня 2013 р.№ 806 [Електронний ресурс]. - Режим доступу : http://zakon5.rada.gov.ua/laws/ show/806-2013-ח/ed20140828/conv.

17. Про затвердження Порядку видачі свідоцтва про допущення дорожнього транспортного засобу до перевезення товарів під митними печатками та пломбами : Наказ Міністерства фінансів України: 09.10.2012 № 1064 [Електронний ресурс]. - Режим доступу : http://zakon3.rada.gov.ua/ laws/show/z1787-12.

18. Про затвердження Порядку надання складським об'єктам статусу «митний склад» та позбавлення такого статусу : Наказ Міністерства фінансів України: від 16.07.2012 № 835 // Офіційний вісник Укра- 
їни від 20.08.2012. - 2012. - № 61. - С. 135. - ст. 2491

19. Про утворення територіальних органів Державної фіскальної служби та визнання такими, що втратили чинність, деяких актів Кабінету Міністрів України : Постанова Кабінету Міністрів України: від 6 серпня 2014 № $311 / /$ Офіційний вісник України від 19.08.2014. - 2014. - № 64. С. 26. - ст. 1765 .

20. Путило Н. В. Публичные услуги: между доктринальным пониманием и практикой нормативного закрепления / Н. В. Путило // Журнал российского права. - 2007. - № 6. - С. 3-10.

21. Словник української мови: в 11 томах. / АН УРСР. Інститут мовознавства; за ред. І. К. Білодіда. - К. : Наукова думка Том 4, 1973. - 839 с.

22. Философский энциклопедический словарь. М. : Советская энциклопедия / гл. редакция: $\Lambda$. Ф. Ильичёв, П. Н. Федосеев, С. М. Ковалёв, В. Г. Панов. - М. : Сов. Энциклопедия, 1983. - 840 с.

SUMMARY
The purpose of the scientific article is to cover
the classification of public services in the field of
tax collection. The methods of the article are a set
of modern methods and techniques of cognition of
objective reality, which combines both general and
special methods of cognition. The basis of the study
is a dialectical method of cognition, according to
which the problems considered in the dissertation
are presented in the form of unity of their social
content and legal form.
The results are a review of different approaches
to the classification of public services in the field of
tax collection and gives its own classification of the
provision of these services. According to the content
criterion, we propose to distinguish the following
public services in the field of tax collection: regis-
tration (for example, registration of the book of in-
come and the book of income and expenses to single
taxpayers; registration of the registrar of settlement
transactions; registration of the value added tax-
payer, etc.); licensing (renewal of the license for the
right to store fuel; issuance of a license for the right
to retail trade in alcoholic beverages; issuance of a
license for the right to retail trade in tobacco prod-
ucts; issuance of a license for the right to wholesale
wholesale ethyl alcohol certifying or reference (for
example, the issuance of a certificate of declaration
of property and income (tax return); Issuance of
a certificate of declaration of property and income
(tax return); issuance of a certificate of payment of
tax liabilities by a taxpayer - a resident who goes
abroad for permanent residence, and the absence
of tax liabilities; information (providing an extract
from the register of single taxpayers; providing an
extract from the Register of non-profit institutions
and organizations; providing an extract from the
register of value added taxpayers, etc.).
Key words: service, types, public service, classi-
fication, classification of public services in the field
of tax collection.

